\title{
Sensory and physicochemical characteristics of salamis added with vegetable-based curing ingredients
}

\section{Vicky Lilge Kawski ${ }^{1 *}$ Teresinha Marisa Bertol ${ }^{1}$ Maria José Honorato dos Santos ${ }^{2}$ Maristela Cortez Sawitzki ${ }^{3}$ Angela Maria Fiorentini ${ }^{4}$ Arlei Coldebella ${ }^{1}$ Ingrid Beatriz Lermen Agnes ${ }^{5}$}

\author{
${ }^{1}$ Embrapa Suínos e Aves, BR 153, KM 110, Vila Tamanduá, 89715-899, Concórdia, SC, Brasil. E-mail: vicky.kawski@embrapa.br. \\ ${ }^{*}$ Corresponding author. \\ ${ }^{2}$ Associação de Pequenos Agricultores do Oeste Catarinense (APACO), Chapecó, SC, Brasil. \\ ${ }^{3}$ Universidade Federal do Pampa (UNIPAMPA), Campus Uruguaiana, Uruguaiana, RS, Brasil. \\ ${ }^{4}$ Universidade Federal de Pelotas (UFPEL), Campus Capão do Leão, Pelotas, RS, Brasil. \\ ${ }^{5}$ Universidade Do Contestado, Concórdia, SC, Brasil.
}

\begin{abstract}
The aim of this study was to evaluate the sensory and physicochemical quality of colonial salamis added with vegetable-based curing ingredients as potential enhancers of quality products. Salamis were produced according to three treatments: (A) Control: $0.1 \%$ curing salt; (B) rosemary: $0.05 \%$ curing salt $+0.5 \%$ rosemary extract $(R E)$; and $(C) R E+$ celery: $0.14 \%$ Veg $503+0.27 \%$ Veg 504 (sea salt plus celery, nitrate and nitrite supplies, respectively) $+0.5 \%$ of $R E$. No significant differences were observed ( $P>0.05)$ among the three treatments for dry matter (DM), crude protein $(C P)$, ash, ether extract (EE) and gross energy (GE). Sensory analysis was performed by applying the preference test and multiple comparison between the three treatments. Salamis added with vegetable-based curing ingredients were sensory equivalent to conventional level of curing salts. Vegetable extracts allowed the development of the sensory features of salami and did not interfere in the fermentation process. Results suggested that the extracts can serve as effective natural curing ingredients for the ripening process and cured meat color as well as adequate shelf-life replacing the commercial curing salts in meat and meat products. After 30 days of ripening, salami from the control treatment (conventional levels of nitrite and nitrate) and the treatments with added vegetable-based curing ingredients and low nitrite and nitrate content (RE and $R E+$ celery) were equivalent in sensory quality.

Key words: celery, curing salt, meat products, rosemary, vegetable extracts.
\end{abstract}

\section{Caracterização sensorial e físico-química de salames adicionados de ingredientes de cura à base de vegetais}

RESUMO: O objetivo deste estudo foi avaliar a qualidade sensorial e físico-química de salames coloniais contendo ingredientes de cura à base de vegetais e, portanto, potenciais intensificadores da qualidade dos produtos. Os salames foram produzidos de acordo com três tratamentos: (A) Controle: 0,1\% de sal de cura; (B) Alecrim: 0,05\% sal de cura + 0,5\% extrato de alecrim (EA); e (C) Alecrim + aipo: $0,14 \%$ Veg $503+0,27 \%$ Veg 504 (sal marinho e aipo, nitrato e nitrito, respectivamente) $+0,5 \%$ do EA. Não foram observadas diferenças significativas $(P>0,05)$ entre os três tratamentos na matéria seca $(M S)$, proteína bruta $(P B)$, cinzas, extrato etéreo (EE) e energia bruta (EB). A análise sensorial foi realizada por meio do teste de comparação múltipla e preferência entre os três tratamentos. Os salames com ingredientes de cura à base de vegetais adicionados para a cura natural foram sensorialmente equivalentes aos salames contendo níveis convencionais de sais de cura. Os extratos vegetais permitiram o desenvolvimento normal das características sensoriais nos salames e não interferiram no processo de fermentação. Os resultados sugerem que os extratos podem servir como efetivos ingredientes naturais de cura para o processo de maturação e formação de cor, além de prolongar a vida-de-prateleira dos produtos, substituindo os sais de cura comerciais usados em carnes e produtos cárneos. Após 30 dias de maturação, os salames do tratamento controle (níveis convencionais de nitrito e nitrato) e os tratamentos contendo ingredientes de cura à base de vegetais e baixo teor de nitrito e nitrato (EA e EA + aipo) foram equivalentes em qualidade sensorial. Palavras-chave: aipo, alecrim, extratos vegetais, produtos cárneos, sal de cura.

\section{INTRODUCTION}

The concept of healthiness associated with changes in the supply chain structure and greater food awareness of the population has been influencing consumption patterns, requiring adaptation by the industry in order to guarantee safe products and quality (ESPÍNDOLA, 2002). To attend this demand the Brazilian law requires cure salt addition (nitrite and nitrate potassium or sodium) in meat products for ensuring the microbiological safety, reduce fat and protein oxidation as well as to improve the sensory characteristics (PARDI et al., 1996; BRASIL, 2000).

Curing salts act in the color development process of sausage and its association with antioxidants contributes to the process of taste development, flavor and sensory quality, as well as extends the shelf life (PÉREZ-CACHO, 2005; DESCALZO \& SANCHO, 2008; BERTOL et al., 2012). Reduction of nitrate to 
nitrite by nitrate-reducing bacteria can promote the formation of these compounds called nitrosamines (MARCO et al., 2006).

Some additives commonly used by the industry such as butylated hydroxyanisole (BHA), butylated hydroxytoluene (BHT), propyl gallate (PG) and tert-butyl-hydroquinone (TBHQ) (CIRIANO, 2009) are potentially toxic. The use of these additives is questionable due to the possibility for yielding carcinogenic processes, so their use in foods is prohibited in some countries (WANASUNDARA \& SHAHIDI, 1998; BOZKURT, 2006).

One of the alternatives to replace the chemical additives for cured products are vegetablebased curing ingredients (SANTAMARIA, 2006). Among some benefits of the addition of vegetable extracts is the capacity to improve the quality and shelf life of products without adding other additives (SANTAMARIA, 2006; MALEKI et al., 2016). The antioxidant effect, preventing rancidity; and therefore, stabilizing the fat, besides their similar action to commercial additives, make vegetable extracts a potentially applicable and healthier option for improving meat products (BASMACIOGLU et al., 2004).

Some examples of vegetable extracts are the celery, rosemary, garlic, onion, cumin, ginger, nutmeg and peppers, commonly used as condiments in meat industry, besides other sources of vegetable extracts such as yerba mate and marcela (BASMACIOGLU et al., 2004). The rosemary extracts and celery powder are easily obtained and used by industry. Among other advantages from this extracts it is worth mentioning their great potential as natural antioxidants, as well as lower health risk compared to synthetic additives.

Rosemary extract has potent antioxidant activity attributed to flavonoid compounds (SEBRANEK, 2005; BOZKURT, 2006; GEORGANTELIS, 2007), while celery powder serving as a natural source of nitrite can be the primary source of natural curing ingredients (SINDELAR et al., 2007; 2015). Given the concern about food safety by the population and the expectative of the industry for healthier alternatives, the aim of this study was to evaluate the effect of addition of rosemary extract and celery-based products in salami as substitutes of conventional curing salts on the sensory and physicochemical characteristics in different ripening times.

\section{MATERIALS AND METHODS}

\section{Preparation of salamis}

The pork cuts used for salami production were obtained from animals from the Embrapa
Swine and Poultry (Concórdia, Santa Catarina State, Brazil), slaughtered at an abattoir with municipal sanitary inspection, and consisted of $60 \%$ ham, 30\% shoulder, and $10 \%$ back-fat, all ground into uniform in size. Deboning of carcasses was performed 24 hours after slaughter, and the meat was cooled for 48 hours. After this period, meat and fat were ground, and the ingredients were added according to three treatments: (A) Control: Addition of $0.1 \%$ curing salt; (B) rosemary: Addition of $0.05 \%$ curing salt $+0.5 \%$ deodorized rosemary oil extract; and $(\mathrm{C})$ rosemary + celery: Addition of $0.14 \%$ extract Veg $503+0.27 \%$ extract Veg 504 (both formulated with celery powder and sea salt) $+0.5 \%$ deodorized rosemary oil extract. The rosemary extract and the Veg Stable compounds (503 and 504) were purchased from commercial companies, Fuchs Gewürze of Brazil Ltda and Florida Food Products, INC, respectively. The inclusion level of celery powder was determined according to the level of nitrite and nitrate determined by analysis of the extract. The inclusion level of rosemary extract was based on concentrations known by industry and mean values referenced in some studies evaluating natural antioxidants (JUNG et al., 2011), because Brazilian legislation does not determine minimum quantities required in meat and by-products (BRASIL, 1998).

The formulation used in each treatment is described in BERTOL et al. (2012). The sausages were manufactured at the Federal Institute of Education, Science and Technology of Santa Catarina - Campus Concórdia, Concórdia, SC. Four replicates (batches) were performed for each treatment. A portion of approximately $350 \mathrm{~g}$ of the mixture was stuffed into synthetic cellulose casings ( $55 \mathrm{~mm}$ diameter), smoked at $25^{\circ} \mathrm{C}$ for 8 hours, and ripened under controlled humidity (average 65\%) for 12 days. Afterwards, the salami was stored under room temperature and humidity until the end of the ripening period (30 days).

At $0,6,12,18,24$, and 30 days of ripening, the salami samples were randomly gathered for physical and chemical analysis. All tests were performed in duplicate.

\section{Sensory analysis}

Sensory analysis was performed with salami collected at 12, 18, 24 and 30 days of curing. Each test was performed with minimum interval of one hour and half after breakfast and before lunch. Tasters were recruited through personal questionnaire and signing of free and informed consent form. The tasters received the necessary guidance before sensory evaluation to avoid interfering in the ratings. Sensory panel was made up of 30 tasters for each lot. Sensory analysis was applied according to NBR 12806 (ABNT, 1993). 
The tasters received the salami samples in a plastic dish, one of each treatment cut into disks of approximately $3 \mathrm{~mm}$ thick, coded with three digits. The tasters evaluated the samples according to their preference by multiple comparisons and ordering test from the most to the less preferred. For multiple comparisons, the tasters received the salami samples from all treatments each time. They evaluated the samples from $12^{\text {th }}$ day ripening and every 6 days after. It was evaluated the order of preference for appearance, odor, flavor, texture and the set of all attributes (MINIM, 2006).

\section{Proximate composition}

Salamis were thawed, ground and frozen for 24 hours and then lyophilized. The physicochemical and gross energy analyses were made in the lyophilized sample. Dry matter (DM) and ash (AS) analysis were made according to AOAC (1995). The crude protein value (CP) was determined using the Kjeldahl method, and fat analysis (FA) was made by Soxhlet extraction method (AOAC, 1995). The gross energy (GE) was determined according to the Operation Manual Leco AC-350. Microbiological analyzes were done and presented at BERTOL et al. (2012).

\section{Statistical analysis}

The composition and gross energy data were analyzed using the MIXED procedure of SAS for repeated measures (SAS Institute Inc., 2001) considering the effect of treatment and block (batch) as the main plot, ripening time as the secondary plot, and the interaction between treatments and ripening time as sources of variation. Sixteen matrices of variance and covariance were evaluated, and the matrix that best fit the data was identified considering the Akaike's Information Criterion (AIC), according to XAVIER (2000). The restricted maximumlikelihood estimation method was used. Treatment means were compared by Tukey's test $(\mathrm{P}<0.05)$.

Data of sensory analysis were subjected to Chi-square test for comparison of treatments within each ripening time, using the statistical package SAS (SAS, 2011).

\section{RESULTS AND DISCUSSION}

Physicochemical parameters had a progressive increase during the course of ripening (Table 1). The DM values were progressively higher $(\mathrm{P}<0.001)$ in all treatments due to moisture loss from the normal curing process, with increasing concentration of other components during the ripening time $(\mathrm{P}<0.001)$. There was no difference $(\mathrm{p} \geq 0.05)$ among treatments for chemical parameters analyzed. Significant differences were observed $(\mathrm{P}<0.05)$ in appearance/color, odor, flavor, texture and the set of all attributes among treatments at specific curing times (Table 2). Differences among treatments were most important in the shorter ripening times. At 12 days of ripening the control treatment was better evaluated by the tasters regarding the appearance $(\mathrm{P}<0.05)$, with $56 \%$ of preference. However, the analysis of the appearance may have been influenced by the dehydrating ring in some samples, mainly in the first two replications. The problem was appointed by tasters mainly at the $30^{\text {th }}$ ripening day.

Regarding the texture, significant differences were reported $(\mathrm{P}<0.05)$ between treatments at 12 and 30 days of ripening. At $30^{\text {th }}$ day the RE and $\mathrm{RE}+$ celery treatments were better valued, showing a positive effect of rosemary and celery powder on the texture at the end of the ripening time of salamis. Odor and flavor attributes were better valued in the control treatment at $12^{\text {th }}, 18^{\text {th }}$ and $24^{\text {th }}$ day $(\mathrm{P}<0.05)$, with the preference of $49-55 \%$ of tasters. For the same features at $30^{\text {th }}$ ripening day there were no differences among treatments. For the set of all attributes, significant differences were observed among treatments $(\mathrm{P}<0.05)$ at 12,18 and 24 days of ripening and the control was the best valued treatment.

At the $30^{\text {th }}$ day there was no difference between treatments, a positive result which indicated that the extracts can replace chemical additives without sensory loss. Similar results were reported by SEBRANEK et al. (2005) and BOZKURT (2006). These authors evaluated rosemary extract and green tea, respectively, and did not identify atypical sensory attributes in fermented products.

Results obtained in the present study are in agreement with the findings of SINDELAR et al. (2007) and CIRIANO et al. (2009), who evaluated products in which different concentrations of celery and Borago officinalis extracts were added, respectively, in order to determine the antioxidant effect and acceptability of fermented products and demonstrated that increased aging time improved the flavor of these products compared to the control treatment. CIRIANO et al. (2009) showed no significant differences between treatments when analyzed the attributes odor, taste and appearance in salamis. Concerning appearance, the salamis containing celery and Borago officinalis extracts were the best valued.

All the sensorial characteristics were most noticeable in the early periods of ripening due to the 
Table 1 - Mean values, standard errors and descriptive levels of probability for F test using repeated measures of physical and chemical parameters.

\begin{tabular}{|c|c|c|c|c|}
\hline \multirow{2}{*}{ RipT, days } & \multicolumn{4}{|c|}{--Treatment--- } \\
\hline & Control & RE & RE+celery & $\operatorname{Pr}>\mathrm{F}$ treatment \\
\hline \multicolumn{5}{|c|}{ 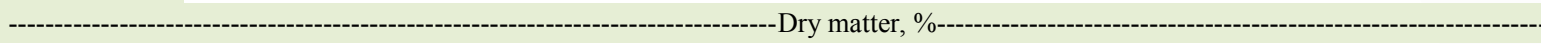 } \\
\hline 0 & $33.64 \pm 0.21 \mathrm{f}$ & $33.01 \pm 0.35 \mathrm{f}$ & $32.99 \pm 0.53 \mathrm{f}$ & 0.854 \\
\hline 6 & $44.57 \pm 1.75 \mathrm{e}$ & $45.51 \pm 2.36 \mathrm{e}$ & $42.53 \pm 2.25 \mathrm{e}$ & 0.694 \\
\hline 12 & $53.27 \pm 0.52 \mathrm{~d}$ & $49.88 \pm 1.73 \mathrm{~d}$ & $49.62 \pm 2.01 \mathrm{~d}$ & 0.373 \\
\hline 18 & $58.47 \pm 2.69 \mathrm{c}$ & $55.72 \pm 2.68 \mathrm{c}$ & $55.81 \pm 2.46 \mathrm{c}$ & 0.756 \\
\hline 24 & $63.69 \pm 1.91 b$ & $62.18 \pm 2.01 \mathrm{~b}$ & $63.52 \pm 1.21 b$ & 0.848 \\
\hline 30 & $67.59 \pm 1.74 a$ & $65.50 \pm 1.78 \mathrm{a}$ & $66.08 \pm 1.41 \mathrm{a}$ & 0.687 \\
\hline $\operatorname{Pr}>$ F RipT & 0.001 & 0.001 & 0.001 & \\
\hline \multicolumn{5}{|c|}{ 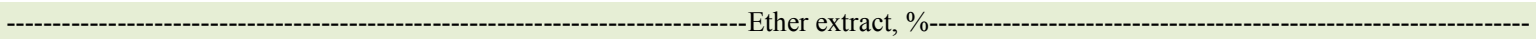 } \\
\hline 0 & $11.68 \pm 0.44 d$ & $10.81 \pm 0.58 \mathrm{~d}$ & $10.23 \pm 0.57 \mathrm{~d}$ & 0.223 \\
\hline 6 & $15.32 \pm 0.51 \mathrm{c}$ & $15.42 \pm 0.93 c$ & $14.36 \pm 0.41 \mathrm{c}$ & 0.590 \\
\hline 12 & $18.41 \pm 0.59 \mathrm{~b}$ & $18.93 \pm 1.34 \mathrm{~b}$ & $16.54 \pm 0.40 \mathrm{bc}$ & 0.179 \\
\hline 18 & $20.15 \pm 1.38 \mathrm{ab}$ & $18.78 \pm 1.14 \mathrm{abc}$ & $20.33 \pm 2.85 \mathrm{ab}$ & 0.811 \\
\hline 24 & $23.74 \pm 1.34 \mathrm{a}$ & $22.35 \pm 1.64 \mathrm{a}$ & $20.90 \pm 0.57 \mathrm{a}$ & 0.359 \\
\hline 30 & $22.67 \pm 0.98 \mathrm{a}$ & $21.48 \pm 0.67 \mathrm{ab}$ & $21.48 \pm 0.92 \mathrm{a}$ & 0.550 \\
\hline $\operatorname{Pr}>$ F RipT & 0.001 & 0.001 & 0.001 & \\
\hline \multicolumn{5}{|c|}{ 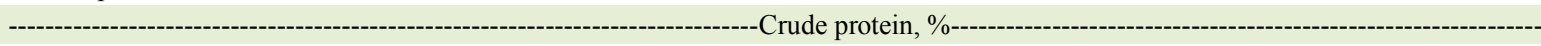 } \\
\hline 0 & $16.57 \pm 0.68 \mathrm{f}$ & $16.68 \pm 0.75 f$ & $16.85 \pm 0.68 \mathrm{f}$ & 0.398 \\
\hline 6 & $22.04 \pm 1.78 \mathrm{e}$ & $22.45 \pm 1.51 \mathrm{e}$ & $20.63 \pm 2.31 \mathrm{e}$ & 0.557 \\
\hline 12 & $26.75 \pm 0.80 \mathrm{~d}$ & $23.99 \pm 2.73 d$ & $25.31 \pm 1.84 \mathrm{~d}$ & 0.480 \\
\hline 18 & $29.25 \pm 2.30 \mathrm{c}$ & $28.20 \pm 2.34 \mathrm{c}$ & $28.49 \pm 2.39 \mathrm{c}$ & 0.925 \\
\hline 24 & $33.58 \pm 0.73 b$ & $33.17 \pm 1.19 b$ & $33.73 \pm 0.39 b$ & 0.858 \\
\hline 30 & $35.64 \pm 0.92 \mathrm{a}$ & $35.01 \pm 1.15 \mathrm{a}$ & $35.39 \pm 0.87 \mathrm{a}$ & 0.917 \\
\hline $\operatorname{Pr}>$ F RipT & 0.001 & 0.001 & 0.001 & \\
\hline \multicolumn{5}{|c|}{ - } \\
\hline 0 & $3.30 \pm 0.286 \mathrm{f}$ & $3.54 \pm 0.111 \mathrm{f}$ & $3.68 \pm 0.071 \mathrm{f}$ & 0.468 \\
\hline 6 & $4.64 \pm 0.304 \mathrm{e}$ & $4.82 \pm 0.244 \mathrm{e}$ & $4.57 \pm 0.360 \mathrm{e}$ & 0.621 \\
\hline 12 & $5.57 \pm 0.192 d$ & $5.26 \pm 0.316 \mathrm{~d}$ & $5.46 \pm 0.324 d$ & 0.302 \\
\hline 18 & $6.22 \pm 0.412 c$ & $5.98 \pm 0.324 c$ & $6.12 \pm 0.328 \mathrm{c}$ & 0.227 \\
\hline 24 & $6.70 \pm 0.359 b$ & $6.65 \pm 0.419 b$ & $6.73 \pm 0.303 b$ & 0.949 \\
\hline 30 & $7.26 \pm 0.292 a$ & $7.06 \pm 0.243 a$ & $7.38 \pm 0.128 \mathrm{a}$ & 0.396 \\
\hline $\operatorname{Pr}>$ F RipT & 0.001 & 0.001 & 0.001 & \\
\hline \multicolumn{5}{|c|}{ 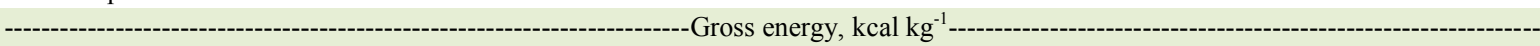 } \\
\hline 6 & $2617.4 \pm 119 \mathrm{c}$ & $2826.0 \pm 366 \mathrm{c}$ & $2442.5 \pm 90.0 \mathrm{~d}$ & 0.102 \\
\hline 12 & $3318.0 \pm 46.4 b$ & $3151.3 \pm 112 b c$ & $3089.6 \pm 103 c$ & 0.165 \\
\hline 18 & $3715.4 \pm b$ & $3797.9 \pm \mathrm{a}$ & $3661.0 \pm b$ & 0.838 \\
\hline 30 & $4211.7 \pm 132 \mathrm{a}$ & $4060.1 \pm 110 \mathrm{a}$ & $4070.4 \pm 97.9 \mathrm{a}$ & 0.370 \\
\hline $\operatorname{Pr}>$ F RipT & 0.001 & 0.001 & 0.001 & \\
\hline
\end{tabular}

RipT = ripening time. RE: rosemary extract. Means followed by different lower case on the row are significantly different $(P<0.05)$ using $M I X E D$ procedure for repeated measures and compared by Tukey's test $(P<0.05)$; nd= not determined.

humidity in the sample, intense acidification and the presence of a starter culture. At the end of ripening time the salami showed an improvement of sensory attributes, consequently it was more difficult to distinguish atypical ingredients added to the product and to identify possible effects on the quality, such as color changes, taste or aroma among treatments.
Conversely, SINDELAR et al. (2007) identified improvements in the sensorial characteristics of fermented products evaluated over time.

Color formation and ripening process in the treatments with reduced content of added nitrites and nitrates (RE and RE + celery) occurred in a similar manner to what occurs in commercial products with 
Table 2 - Means of frequencies and percentages of preference of tasters for each sensory attribute evaluated in different ripening times by Chi-square test $\left(\chi^{2}\right)$.

\begin{tabular}{|c|c|c|c|c|c|}
\hline \multirow{2}{*}{ Dependent variables } & \multirow{2}{*}{ Treatment } & \multicolumn{4}{|c|}{ 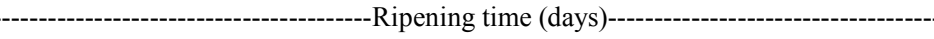 } \\
\hline & & 12 & 18 & 24 & 30 \\
\hline \multirow{5}{*}{ Appearance } & Control & $56(56.00) \mathrm{a}$ & $36(41.38)$ & $34(30.09)$ & $29(28.71)$ \\
\hline & $\mathrm{RE}$ & $22(22.00) b$ & $26(29.89)$ & $38(33.63)$ & $31(30.69)$ \\
\hline & $\mathrm{RE}+$ celery & $22(22.00) b$ & $25(28.74)$ & $41(36.28)$ & $41(40.59)$ \\
\hline & No. tasters ${ }^{1}$ & 100 & 87 & 113 & 101 \\
\hline & $\operatorname{Pr}>\chi^{2}$ Treatment & $<0.001$ & 0.279 & 0.721 & 0.293 \\
\hline \multirow{5}{*}{ Odor } & Control & $50(52.63) \mathrm{a}$ & $44(48.35) \mathrm{a}$ & $54(53.47) \mathrm{a}$ & $29(28.71)$ \\
\hline & $\mathrm{RE}$ & $28(29.47) \mathrm{a}$ & $25(27.47) b$ & $24(23.76) b$ & $37(38.95)$ \\
\hline & $\mathrm{RE}+$ celery & $17(17.89) b$ & $22(24.18) b$ & $23(22.77) b$ & $29(30.53)$ \\
\hline & No. tasters ${ }^{1}$ & 95 & 91 & 101 & 95 \\
\hline & $\operatorname{Pr}>\chi^{2}$ Treatment & 0.0001 & 0.009 & $<.0001$ & 0.510 \\
\hline \multirow{5}{*}{ Flavor } & Control & $46(49.46) \mathrm{a}$ & $45(50.56) \mathrm{a}$ & $59(55.14) \mathrm{a}$ & $31(33.33)$ \\
\hline & $\mathrm{RE}$ & $31(33.33) \mathrm{a}$ & $18(20.22) b$ & $23(21.50) \mathrm{b}$ & $37(39.78)$ \\
\hline & $\mathrm{RE}+$ celery & $16(17.20) \mathrm{b}$ & $26(29.21) b$ & $25(23.36) \mathrm{b}$ & $25(26.88)$ \\
\hline & No. Tasters ${ }^{1}$ & 93 & 89 & 107 & 93 \\
\hline & $\operatorname{Pr}>x^{2}$ Treatment & 0.0007 & 0.002 & $<.0001$ & 0.313 \\
\hline \multirow{5}{*}{ Texture } & Control & $41(47.67) a$ & $32(36.78)$ & $41(36.28)$ & $18(17.82) b$ \\
\hline & $\mathrm{RE}$ & $28(32.56) \mathrm{ab}$ & $25(28.74)$ & $39(34.51)$ & $42(41.58) \mathrm{a}$ \\
\hline & $\mathrm{RE}+$ celery & 17 (19.77)b & $30(34.48)$ & $33(29.20)$ & 41 (40.59)a \\
\hline & No. Tasters ${ }^{1}$ & 86 & 87 & 113 & 101 \\
\hline & $\operatorname{Pr}>x^{2}$ Treatment & 0.007 & 0.639 & 0.631 & 0.004 \\
\hline \multirow{5}{*}{ Set of all atributes } & Control & $54(56.84) \mathrm{a}$ & $48(52.75) \mathrm{a}$ & $48(44.04)$ & $32(33.68)$ \\
\hline & $\mathrm{RE}$ & $27(28.42) b$ & $19(20.88) b$ & $30(27.52)$ & $33(34.74)$ \\
\hline & $\mathrm{RE}+$ celery & $14(14.74) c$ & $24(26.37) b$ & $31(28.44)$ & $30(31.58)$ \\
\hline & No. Tasters ${ }^{1}$ & 95 & 91 & 109 & 95 \\
\hline & $\operatorname{Pr}>\chi^{2}$ Treatment & $<0.0001$ & 0.0004 & 0.060 & 0.930 \\
\hline
\end{tabular}

Control: $0.1 \%$ curing salt; RE: $0.05 \%$ curing salt $+0.5 \%$ rosemary extract; RE + celery: $0.14 \%$ commercial extract Veg $503+0.27 \%$ commercial extract Veg 504 celery powder $+0.5 \%$ rosemary extract. Means followed by different lower case on the row are significantly different $(\mathrm{p}<0.05)$ by Chi-square test; ${ }^{1}$ Number of tasters was the sum of tasters in each batch of salami evaluated.

conventional content of curing salts (MARCO et al., 2006). Addition of rosemary oil and celery extract did not affect the growth of the starter culture added to the salami (BERTOL et al., 2012).

The absence of noticeable difference in the odor of salami at 30 days of ripening, suggested that at the end of the process of fermentation and ripening may have occurred volatilization of the compounds that give the characteristic aroma of rosemary (BERTOL et al., 2012). Concentration of the flavor and odor of other ingredients added to the dough as a function of moisture loss makes more difficult the identification and differentiation of specific compounds. Unlike what happened at 30 days, at the beginning of ripening the moisture associated with the characteristic odor of extracts in the samples made easier the identification of the same by the judges.
Regarding the results obtained in the preference test for multiple comparison procedure, it was observed that adding different combinations of plant extracts in the formulations may have interfered in the preference of tasters. While there is no interference in the residual levels of nitrite (BERTOL et al., 2012), the addition of extracts influenced the preference of tasters in color during the initial period of ripening. Unusual flavor conferred by rosemary and the celery when compared to the salami traditionally marketed, mainly in the early ripening period, influences the opinion of the tasters because consumers of fermented sausages products such as salami are accustomed to a predefined flavor characteristic of the commercial product consumed regularly.

According to CASABURI et al. (2007), factors such as the use of a starter culture can also 
influence the sensory characteristics of fermented products because when combined with the use of nitrite and nitrate, the culture promotes intensification of the effect thereof (CASABURI et al., 2007). However, it is not possible to say what is the specific cause of this effect, if it is due to the acidification promoted by the starter cultures, the action of enzymes present in the meat, the action of mold present on the surface, or the proteolytic and lipolytic activity of microbial enzymes (TERRA, 2005; CASABURI et al., 2007).

\section{CONCLUSION}

The rosemary extract and celery powder allowed the normal development of sensory attributes in salami, but in a longer time, without impairing the fermentation and ripening. At the end of the ripening period naturally cured salami was sensory equivalent to the salami prepared with conventional levels of curing salts. Therefore, the replacement of curing salts by vegetable-based curing ingredients is possible and may represent a potential benefit on human health.

\section{BIOETHICS AND BIOSSECURITY COMMITTEE APPROVAL}

This study was approved by the Local Research Ethics Committee (COLEP) of the Universidade do Contestado (UnC), Concordia, Santa Catarina by advice embodied (protocol) No 469/08.

\section{REFERENCES}

ASSOCIATION OF OFFICIAL ANALYTICAL CHEMISTS (AOAC). Official methods of analysis of the Association of Official Analytical Chemists. Arlington: AOAC,1995. Chapt.39, p.13-15.

BASMACIOGLU, H. et al. The effect of oregano and rosemary oils alpha-tocopheryl acetate on performance and lipid oxidation of meat enriched with n-3 PUFA's in broilers. South African Journal of Animal Science, v.34, n.3, p.197-210, 2004. Available from: <http:// eds.b.ebscohost.com/eds/pdfviewer/pdfviewer?sid=22e22eb55347-4df3-9f2b-6883316c32cd\%40sessionmgr101\&vid=0\&h id=114>. Accessed: Mar. 25, 2015 .

BERTOL, T.M. et al. Rosemary extract and celery-based products used as natural quality enhancers for colonial type salami with different ripening times. Ciência e Tecnologia de Alimentos, v.32, n.4, p.783-792, 2012. Available from: <http://www.scielo.br/ scielo.php?script=sci_arttext\&pid=S0101-20612012000400022>. Accessed:Mar.25,2015. doi: 10.1590/S0101-20612012005000110.

BOZKURT, H. Utilization of natural antioxidants: Green tea extract and Thymbra spicata oil in Turkish dry-fermented sausage. Meat Science, v.73, p.442-450, 2006. Available from: <http:// ahoramazda2481.persiangig.com/anti/10.pdf/download?7a92>. Accessed: Jun. 17, 2015. doi: 10.1016/j.meatsci.2006.01.005.

BRASIL. Ministério da Agricultura Pecuária e Abastecimento. Instrução Normativa $\mathrm{n}^{\circ} 22$, de 31 de julho de 2000. Anexo V:
Regulamento técnico de identidade e qualidade de salame. Diário Oficial da República Federativa do Brasil, Brasília, DF, Aug. 03, 2000. Seção 1, p.15.

BRASIL. Agência Nacional de Vigilância Sanitária. Portaria $\mathrm{n}^{\circ} 1004$, de 11 de dezembro de 1998. Regulamento Técnico: Atribuição de Função de Aditivos, Aditivos e seus Limites Máximos de uso para Carne e Produtos Cárneos. Diário Oficial da União, Brasília, DF, Dec. 14, 1998.

CASABURI, A. et al. Biochemical and sensory characteristics of traditional fermented sausages of Vallo di Diano (Southern Italy) as affected by the use of starter cultures. Meat Science, v.76, p.295-307, 2007. Available from: <https://www.researchgate.net/ publication/51778367>. Accessed: Oct. 10, 2015. doi: 10.1016/j. meatsci.2006.11.011.

CIRIANO, M.G.I. de et al. Use of natural antioxidants from lyophilized water extracts of Borago officinalis in dry fermented sausages enriched in $\omega-3$ PUFA. Meat Science, v.83, p.271-277, 2009. Available from: <https://www.deepdyve.com/lp/elsevier/>. Accessed: May 13, 2015. doi: 10.1016/j.meatsci.2009.05.009.

DESCALZO,A.M.; SANCHO,A.M.A review of natural antioxidants and their effects on oxidative status, odor and quality of fresh beef produced in Argentina. Meat Science, v.79, p.423-436, 2008. Available from: $<$ https:// www.researchgate.net/publication/222669516/>. Accessed: Nov. 21, 2016. doi: 10.1016/j.meatsci.2007.12.006.

ESPÍNDOLA, C.E. Tecnology and new relations of work in the agricultural industries of meat of the south of Brazil. Revista Electrónica De Geografía Y Ciencias Sociales, Universidad de Barcelona. ISSN: 1138-9788. Depósito Legal: B. 21.741-98 v.119, n.85, 1 de agosto de 2002. Available from: <http://www.ub.es/geocrit/ $\mathrm{sn} / \mathrm{sn} 119-85 . \mathrm{htm}>$. Accessed: Nov. 17, 2015. (Electronic publication).

GEORGANTELIS, D. et al. Effect of rosemary extract, chitosan and $\alpha$-tocopherol on microbiological parameters and lipid oxidation of fresh pork sausages stored at $4^{\circ} \mathrm{C}$. Meat Science, v.76, p.172181, 2007. Available from: <http://agris.fao.org/agris-search/search. do?recordID=US201300752975 >. Accessed: Nov. 18, 2013. doi: 10.1016/j.meatsci.2006.10.026.

JUNG, W.S. et al. In vitro antioxidant activity, total phenolics and flavonoids from celery (Apium graveolens) leaves. Journal of Medicinal Plants Research, v.5, p.7022- 7030, 2011. Available from: $<$ http://www.academicjournals.org/journal/JMPR/article-abstract/ F37009E25883 > Accessed: Nov. 17, 2013. doi: 10.5897/JMPR11.1129.

MALEKI, M. et al. Effects of celery extracts on the oxidative stability of canola oil under thermal condition. Journal of Food Processing and Preservation, v.40, p.531-540, 2016. Available from: <https://www.researchgate.net/publication/284281519/>. Accessed: doi: 10.1111/jfpp.12632.

MARCO, A. et al. The influence of nitrite and nitrate on microbial, chemical and sensory parameters of slow dry fermented sausage. Meat Science, v.73, p.660-673, 2006. Available from: <http:// www.academia.edu/19319470/>. Accessed: Mar. 20, 2016. doi: 10.1016/j.meatsci.2006.03.011.

MINIM, V.P.R. Análise sensorial: estudos com consumidores. Viçosa, MG: UFV, 2006.

PARDI, M.C.et al. Ciência Higiene e Tecnologia da Carne. Goiânia: UFG, 1996. V.2, 1110p. 
PÉREZ-CACHO, M.P.R. et al. Determination of the sensory attributes of a Spanish dry-cured sausage. Meat Science, v.71, p.620-633, 2005 Available from: <https://www.ncbi.nlm.nih.gov/pubmed/22061207>. Accessed: Jun. 7, 2013. doi: 10.1016/j.meatsci.2005.05.005.

SANTAMARIA, P. Nitrate in vegetables: toxicity, content, intake and EC regulation. Journal of the Science of Food and Agriculture, v.86, p.10-17, 2006. Available from: <http://onlinelibrary.wiley.com/ doi/10.1002/jsfa.2351/epdf>. Accessed: Mar. 5, 2015. doi: 10.1002 jsfa. 2351 .

SEBRANEK, J.G. et al. Comparison of a natural rosemary extract and BHA/BHT for relative antioxidant effectiveness in pork sausage. Meat Science, v.69, p.289-296, 2005. Available from: $<$ https://www.researchgate. net/publication/51776997/>. Accessed: Mar. 14, 2015. PMID: 22062821 doi: 10.1016/j.meatsci.2004.07.010 (Electronic publication).

SINDELAR, J.J. et al. Effects of varying levels of vegetable juice powder and incubation time on color, residual nitrate and nitrite, pigment, $\mathrm{pH}$, and trained sensory attributes of ready-to-eat uncured ham. Journal of Food Science, v.72, n.6, p.S388-S395, 2007. Available from: <http://www.public.iastate.edu/ duahn/ publication/pdf\%20files/150_JFS-Uncured\%20Ham.pdf $>$. Accessed: Sept. 21, 2015. doi: 10.1111/j.1750-3841.2007.00404.x.

SINDELAR, J.J. Best practices in alternative curing food safety. Available from: <http://www.meatingplace.com/Industry/ TechnicalArticles/Details/53636>. Accessed: Oct. 2015.

STATISTICAL ANALYSIS SYSTEM (SAS). SAS user's guide: statistics. Carry, 2011. Version 8.

TERRA, N.N. Apontamentos de tecnologia de carnes. São Leopoldo: Unisinos, 2005. 216p.

WANASUNDARA U.N.; SHAHIDI F. Antioxidant and prooxidant activity of green tea extracts in marine oils. Food Chemistry, v.63, n.3, p.335-342, 1998. Available from: <http:// agris.fao.org/agris-search/search.do?recordID $=$ GB1997054129>. Accessed: Mar. 11, 2013. doi: 10.1016/S0308-8146(98)00025-9. 